\title{
Tequila vinasses acidogenesis in a UASB reactor with Clostridium predominance
}

\author{
E N Marino-Marmolejo ', L Corbalá-Robles², R C Cortez-Aguilar², S M Contreras-Ramos², R E Bolaños-Rosales² \\ and G Davila-Vazquez ${ }^{2^{*}}$
}

\begin{abstract}
Tequila vinasses represent an acidic, highly concentrated pollutant effluent generated during the distillation step of Tequila production. Although acidogenesis of Tequila vinasses has been reported for some reactor configurations, a characterization of the bacteria present during this metabolic process is lacking in the literature. Hydraulic retention times (HRT) between 36 and $6 \mathrm{~h}$ and organic loading rates (OLR) from 5 to $30 \mathrm{~g} \mathrm{COD} \mathrm{L}^{-1} \mathrm{~d}^{-1}$ were assessed in a UASB reactor fed with Tequila vinasses. Results showed that OLR excerted a stronger effect $(p \leq 0.0001)$ on parameters such as gas production rate, $\mathrm{pH}$, and acidity than HRT. While it was clear that shorter HRT were related to higher volatile fatty acid production levels. Figures above $2 L_{\text {gas }} L_{\text {reactor }}^{-1} d^{-1}$ (where "gas" could be a mixture of methane and hydrogen) were attained only with an OLR as high as $30 \mathrm{~g} \mathrm{COD} \mathrm{L}^{-1} \mathrm{~d}^{-1}$. Bacterial identification of a sludge sample at the end of the experiment revealed that acid-tolerant microorganisms that remained in the reactor were exclusively affiliated to the Clostridium genera, being the first report of organisms identification for Tequila vinasses acidogenesis. These findings are relevant to the field of biotechnology since acidogenesis of Tequila vinasses using identified and studied microorganism abilities (i.e. Clostridium strains) presents the opportunity of optimizing processes intended for different metabolites production (butanol, volatile fatty acids, hydrogen, solvents).
\end{abstract}

Keywords: Stillage, Volatile fatty acid, Biohydrogen, DGGE, Agave

\section{Background}

Total production of the well known mexican spirit called Tequila was around 242.4 million liters in 2014 (CRT 2015b). With seasonal variations in the past decades, Tequila production in the last ten years has nearly doubled (CNIT 2015). Thus, this economic activity is very important for a mexican region comprising 181 municipalities that retain the protected apellation of origin for this representative beverage (CRT 2015a). Being a spirit, Tequila production generates distillery wastewater (i.e. vinasse) in the order of 7-12 L of vinasse per liter of tequila produced and it is characterised for having a brownish color, high content of organic matter, low $\mathrm{pH}$ and high dissolved and suspended solids concentration (Méndez-Acosta et al. 2010; Buitrón et al.

\footnotetext{
*Correspondence: gdv@ciatej.mx

${ }^{2}$ Tecnología Ambiental, Centro de Investigación y Asistencia en Tecnología y Diseño del Estado de Jalisco, Av. Normalistas 800, Col. Colinas de la Normal, C.P. 44270 Guadalajara, Jalisco, Mexico Full list of author information is available at the end of the article
}

2014b; López-López et al. 2010). Therefore, an estimate of Tequila vinasses production in 2014 was around 2,424 million liters and it is considered that only a small fraction of this received treatment before discharging it to water bodies and soil. Few tequila producers have invested in acquiring wastewater treatment plants and installed facilities for reducing the environmental impact of these effluents, being the anaerobic digestion (AD) process the most successful core technology for removing high levels of organic matter together with the production of bioenergy in the form of biogas (Buitrón et al. 2014b). However, it is acknowledged that the AD process is characterized by a delicate syntrophic interaction and dependence between Bacteria and Archaea, which can be upset by changes in some operational parameters and environmental conditions such as $\mathrm{pH}$, substrate concentration, organic loading rate, toxic and/or inhibitory compounds present in complex effluents such as vinasses (Chen et al. 2008; Pant and Adholeya 2007; Silva et al. 2013; Mendez-Acosta et al. 2011). A common

\section{Springer}

(c) 2015 Marino-Marmolejo et al. This article is distributed under the terms of the Creative Commons Attribution 4.0 International License (http://creativecommons.org/licenses/by/4.0/), which permits unrestricted use, distribution, and reproduction in any medium, provided you give appropriate credit to the original author(s) and the source, provide a link to the Creative Commons license, and indicate if changes were made. 
phenomenon that occurs in anaerobic digestors treating tequila vinasses is known as acidification of the system (Ilangovan et al. 2000). This undesirable phenomenon for anaerobic digestion operators has received little attention so far, but it could be considered as an opportunity for hydrogen production and volatile fatty acids (VFA) recovery rather than being an avoidable and unwanted process condition in terms of organic matter reduction with biogas production.

Previous works have described limited biodegradation of tequila vinasses (Retes-Pruneda et al. 2014) or hydrogen and VFA production in batch (Espinoza-Escalante et al. 2008), discontinuous (Buitrón and Carvajal 2010; Espinoza-Escalante et al. 2009; Buitrón et al. 2014a) and continuous (Buitrón et al. 2014b) processes. A batch process was selected by Espinoza-Escalante et al. (2008) to study the effect of pretreatments (alkalinization, thermal treatment and sonication) on tequila vinasse acidogenesis. Total VFA production was between 3,000 and $7,000 \mathrm{mg} \mathrm{L}^{-1}$ with an optimum total hydrogen production of $1,217 \mathrm{~mL}$ (from a $540 \mathrm{~mL}$ reactor working volume). On the other hand, Espinoza-Escalante et al. (2009) studied the effect of three operation parameters (hydraulic retention time (HRT), $\mathrm{pH}$ and temperature) in semi-continuous experiments to optimise the production of $\mathrm{CH}_{4}$ and $\mathrm{H}_{2}$. The authors found the best results for hydrogen production at $\mathrm{pH}=5.5, \mathrm{HRT}=5$ days and temperature $=55^{\circ} \mathrm{C}$, with total VFA production in the order of $154 \mathrm{~g} \mathrm{~L}^{-1}$ and cumulative $\mathrm{H}_{2}$ and $\mathrm{CH}_{4}$ production of 5,600 and 1,230 mL, respectively. These authors also suggested that other parameters such as alkalinity and organic load should be studied in further research.

Anaerobic sequencing batch reactors (AnSBR) had been reported by some authors as suitable systems for hydrogen and VFA production from tequila vinasses. Buitrón and Carbajal (2010), studied the effects of temperature $\left(25\right.$ and $\left.35^{\circ} \mathrm{C}\right)$, HRT of 12 and $24 \mathrm{~h}$ and initial substrate concentration (0.5-5 g of chemical oxygen demand $(\mathrm{COD}) \mathrm{L}^{-1}$ ) on hydrogen production using an AnSBR. Among the factors studied, the most significant was the HRT, with the maximum hydrogen production at $35^{\circ} \mathrm{C}$ and HRT of $12 \mathrm{~h}$. Regarding total VFAs production, the authors found that higher concentrations were attained at HRT of $24 \mathrm{~h}\left(1396 \mathrm{mg}\right.$ VFA L $\left.{ }^{-1}\right)$ compared to $12 \mathrm{~h}\left(77 \mathrm{mg} \mathrm{VFA} \mathrm{L}^{-1}\right)$. Further research by the same group was performed to study hydrogen and methane production from vinasses in two separate reactors (acidogenic + methanogenic) (Buitrón et al. 2014a). For acidogenesis, the authors performed two sets of experiments using two reactors (with different working volumes), in the first one they tested a HRT of $18 \mathrm{~h}$ with $0.5,1.0$ and $5.0 \mathrm{mg}$ soluble COD $\mathrm{L}^{-1}$. The second reactor was operated at $\mathrm{HRT}=6 \mathrm{~h}$ with higher substrate concentrations:
2, 6, 8, 12 and 16 g soluble COD $\mathrm{L}^{-1}$. In both reactors, temperature and $\mathrm{pH}$ were controlled at $35^{\circ} \mathrm{C}$ and 5.5 , respectively. The performance of the reactor operated with the lowest HRT and higher substrate concentration (highest OLR) resulted in a volumetric hydrogen production rate (VHPR) of $57.4 \mathrm{~mL}_{\mathrm{H} 2} \mathrm{~L}^{-1} \mathrm{~h}^{-1}$ and yield of $118 \mathrm{~mL}_{\mathrm{H} 2} \mathrm{~g} \mathrm{COD}^{-1}$. Acetic, propionic and butyric acids were the main VFA detected at a concentration of $160 \mathrm{mg}$ total VFA $\mathrm{L}^{-1}$. A fixed bed reactor was recently studied to assess hydrogen production in a continuous regime (Buitrón et al. 2014b). The authors performed the experiments with a HRT $=4 \mathrm{~h}$ and gradually increased the vinasse feed to the reactor reaching a organic load of $51 \mathrm{~g}$ $\mathrm{COD} \mathrm{L}^{-1} \mathrm{~d}^{-1}$ with $100 \%$ vinasse. Best result for hydrogen production rate was $72 \mathrm{~mL}_{\mathrm{H} 2} \mathrm{~L}^{-1} \mathrm{~h}^{-1}$. Total VFA under continuous regime was around $1756 \mathrm{mg} \mathrm{COD} \mathrm{L}^{-1}$ with acetic acid being the $15.8 \%$, while butyric and i-butyric acids were 29.1 and $27.7 \%$, respectively.

These previous reports had shown that it is feasible to obtain VFA and an energy carrier (biogas and/or hydrogen) from anaerobic digestion of tequila vinasses. However, reported results for VFA production in batch, semi-continuous and continuous regime, are in a wide interval going from $16 \mathrm{mg} \mathrm{L}^{-1}$ to $154 \mathrm{~g} \mathrm{~L}^{-1}$, therefore it is natural to expect that the performance of the systems is dependent on different operation parameters and regime (Davila-Vazquez et al. 2008; Bengtsson et al. 2008). Besides, to the best of our knowledge there is no information regarding the microorganisms that could be responsible for acidogenesis of a complex wastewater such as Tequila vinasses, moreover recent reports also suggested that this characterization could be processdependent (Hernández-Mendoza et al. 2014).

Thus, the aim of this work was the assessment of hydraulic retention time (HRT) and organic loading rate (OLR) on the acidogenesis of Tequila vinasses during a continuous regime using a UASB reactor. The bacterial community adapted and therefore present in the reactor at the end of the experiment was analyzed using polymerase chain reaction-denaturing gradient gel electrophoresis (PCR-DGGE) and the volatile fatty acids produced were analyzed as well.

\section{Methods}

\section{Tequila vinasses}

A batch of 200 liters of tequila vinasse was obtained from a Tequila factory located in Guadalajara, Jalisco, Mexico. The batch was kept at $4^{\circ} \mathrm{C}$ prior it was utilized in the experiments. This factory produces "Tequila $100 \%$ Agave" which according to mexican regulation (NOM006-SCFI-2012) means that all sugars present in the fermentation broth are derived from the Agave head (piña). A characterization of the tequila vinasse was performed 
according either to the Standard Methods (APHA et al. 1998) or $\mathrm{HACH}^{\circledR}$ protocols (Loveland, Colorado, USA). Soluble COD was $40,786 \mathrm{mg} \mathrm{L}^{-1}, \mathrm{pH}=3.81$, Acidity $3,200 \mathrm{mg} \mathrm{CaCO}_{3} \mathrm{~L}^{-1}$, Conductivity $3.01 \mathrm{mS} \mathrm{cm}^{-1}$, Total phosphorous $1,204 \mathrm{mg} \mathrm{L}^{-1}$, Total nitrogen $174.6 \mathrm{mg} \mathrm{L}^{-1}$, Sulfates $103.8 \mathrm{mg} \mathrm{L}^{-1}$.

\section{Experimental procedure}

A jacketed 1.2 L Upflow Anaerobic Sludge Blanket (UASB) glass reactor was used for performing the continuous experiments. The experimental scheme was intended to start with the longest HRT (36 h) and then gradually diminish it to 24, 12, and $6 \mathrm{~h}$. Except for $36 \mathrm{~h}$, at least in each HRT two different OLR were assessed. The reactor was maintained at $37 \pm 1^{\circ} \mathrm{C}$ circulating water from a heated bath.

The biogas produced was conducted through a $\mathrm{NaOH}$ $2 \mathrm{M}$ gas trap for $\mathrm{CO}_{2}$ elimination and after this step it was colected in an graduated acrylic glass cylinder used as a Mariotte bottle. Granular sludge from a full scale UASB reactor intended to Tequila vinasse methanisation was used as inoculum. A $400 \mathrm{~mL}$ granular sludge volume was used, with a volatile solids content of $4.13 \mathrm{~g} \mathrm{~L}^{-1}$. Anaerobic granular sludge used as inoculum seed received no previous treatment (e.g. heat shock, $\mathrm{pH}$ change).

A mineral nutrient solution was added to the feed vinasse solution to keep the concentration as follows: $\mathrm{MgCl}_{2} \cdot 6 \mathrm{H}_{2} \mathrm{O} 10 \mathrm{mg} \mathrm{L}^{-1}$; $\mathrm{MnSO}_{4} \cdot 6 \mathrm{H}_{2} \mathrm{O} 1.5 \mathrm{mg} \mathrm{L}^{-1}$; $\mathrm{FeSO}_{4} \cdot 7 \mathrm{H}_{2} \mathrm{O} 2.5 \mathrm{mg} \mathrm{L}{ }^{-1}$; $\mathrm{CuSO}_{4} \cdot 5 \mathrm{H}_{2} \mathrm{O} 0.5 \mathrm{mg} \mathrm{L}{ }^{-1}$; $\mathrm{CoCl}_{2} 0.3 \mathrm{mg} \mathrm{L}-1 \mathrm{Na}_{2} \mathrm{MoO}_{4}-2 \mathrm{H}_{2} \mathrm{O} 1.25 \mathrm{mg} \mathrm{L}{ }^{-1} ; \mathrm{ZnCl}_{2}$ $0.075 \mathrm{mg} \mathrm{L}{ }^{-1} ; \mathrm{NH}_{4} \mathrm{Cl} 3.0 \mathrm{~g} \mathrm{~L}^{-1} ; \mathrm{KH}_{2} \mathrm{PO}_{4} 7.85 \mathrm{~g} \mathrm{~L}^{-1}$; $\mathrm{K}_{2} \mathrm{HPO}_{4} 7.37 \mathrm{~g} \mathrm{~L}^{-1}$. All chemicals were purchased from Sigma-Aldrich (St. Louis, Missouri, USA) as reagent grade.

Samples $(10 \mathrm{~mL})$ from the reactor effluent were withdrawn every $24 \mathrm{~h}$ for $\mathrm{pH}$, acidity and alkalinity determination by titration methods (APHA et al. 1998). COD was measured three times a week with $\mathrm{HACH}^{\circledR}$ reagents tests (Method 8000). Samples (3 mL) for VFA determination were taken three times a week and were preserved according to Park et al. (2005) and kept at $4^{\circ} \mathrm{C}$ until analysis by gas chromatography.

Volatile fatty acids (VFA) were analyzed by injecting a $0.5 \mu \mathrm{L}$ sample into a gas chromatograph G1530 equipped with a flame ionization detector (Agilent, Wilmington, USA) and a capillary column DB-FAP (30 $\mathrm{m} \times 0.25 \mathrm{~mm}$ i.d. $\times 0.25 \mu \mathrm{m}$ film thickness; Agilent, Wilmington, USA). Helium was used as carrier gas at a flow rate of $1.0 \mathrm{~mL} \mathrm{~min}{ }^{-1}$. Temperatures for the injector and flame ionization detector (FID) were 210 and $240^{\circ} \mathrm{C}$, respectively. The VFA analyses were performed with a split ratio of $1: 20$ and a temperature program starting at $80^{\circ} \mathrm{C}$ for

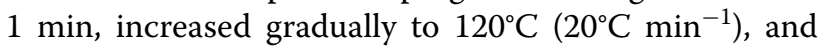

then it was warmed to a final temperature of $205^{\circ} \mathrm{C}$ (at $\left.6 \mathrm{~min}^{-1}\right)$.

Analysis of variance (ANOVA) were performed using Statgraphics ver. Centurion XVI (Statpoint Technologies).

\section{Microbial analysis by PCR-DGGE of partial 16S rRNA genes DNA extraction}

A $15 \mathrm{~mL}$ sludge sample was withdrawn from the bottom of the UASB reactor at the end of the experiment and was stored at $-20^{\circ} \mathrm{C}$ until analysis. Reactor sample was slowly thawed and centrifuged $\left(10,000 \mathrm{rpm}, 10 \mathrm{~min}, 4^{\circ} \mathrm{C}\right)$ to obtain a $200-300 \mathrm{mg}$ sludge pellet, the resulting pellet was washed three times by re-suspension with one milliliter of sterile phosphates-buffered saline buffer $\mathrm{pH} 7.5$ and centrifugation of each preparation. DNA extraction was performed using the ZR Soil Microbe DNA MiniPrep $^{\text {TM }}$ (Zymo Research, California, USA) according to manufacturer instructions. A DNA integrity analysis was performed in $1 \%(\mathrm{w} / \mathrm{v})$ agarose gels, stained with Gel$\operatorname{Red}^{\mathrm{TM}}$ stain (Biotium, California, USA).

\section{PCR amplification}

Amplification of the hypervariable 3 region of the $16 \mathrm{~S}$ rRNA gene from the purified nucleic acids preparations was carried out by PCR reactions and thermal programs where performed as previously described (DavilaVazquez et al. 2011), the PCR primers used were the forward primer C356F (5'-CTACGGGAGGCAGCAG-3') and the reverse primer 517R (5'-ATTACCGCGGCTG CTGG-3'). The primer C356F contains the GC clamp led to carry out the DGGE. The PCR product was loaded onto a $1.5 \%(\mathrm{w} / \mathrm{v})$ agarose gel with $100 \mathrm{bp}$ molecular weight marker and stained with GelGreen ${ }^{\mathrm{TM}}$ stain (Biotium, California, USA) to assess the size (236 bp), purity and concentration of DNA.

\section{DGGE analysis}

DGGE was performed with DCode ${ }^{\mathrm{TM}}$ Universal Mutation Detection System (Biorad, California, USA). The PCR products were loaded onto $10 \%$ polyacrylamide gels in $1 \times$ TAE buffer (20 mM Tris, $10 \mathrm{mM}$ glacial acetic acid, and $0.5 \mathrm{mM}$ EDTA $\mathrm{pH}$ 8.0) with a denaturing gradient (urea-formamide) that ranged from 40 to $70 \%$. Electrophoresis was carried out at $60^{\circ} \mathrm{C}$ and a constant voltage of $70 \mathrm{~V}$ was applied during $14 \mathrm{~h}$. After electrophoresis the gel was stained using GelGreen ${ }^{\mathrm{TM}}$ for 30 min (Biotium, California, USA) before being visualized on a UV transilluminator (Biorad, California, USA). The dominant bands were excised from the gel, eluted in $10 \mathrm{mM}$ Tris- $\mathrm{HCl}$, $50 \mathrm{mM} \mathrm{KCl}, 1.5 \mathrm{mM} \mathrm{MgCl}, 0.1 \%$ Triton-x 100, pH 9.0, at $95^{\circ} \mathrm{C}$ for $20 \mathrm{~min}$ and centrifuged $(10,000 \mathrm{rpm}, 5 \mathrm{~min})$. The DNA was reamplified by PCR with the conditions 
mentioned in the "PCR amplification" section. The PCR products from reamplification were purified and sent to sequencing at Macrogen Service Center (Maryland, USA). Sequence data were analyzed with BioEdit $v 7.1$ software (Ibis Bioscience, California, USA) and submitted to the non-redundant nucleotide data base at GenBank $^{\circledR}$ using the BLAST program (http://www.ncbi.nlm. nih.gov/blast/) and Ribosomal Database Project (http:// rdp.cme.msu.edu/index.jsp) for bacterial identification.

\section{Results}

\section{Reactor performance}

Performance of reactor in terms of $\mathrm{pH}$ and removal of chemical organic demand (COD) is shown in Fig. 1. Phases of operation (from I to X) together with operational conditions (HRT and OLR) are mentioned in the figure legend. Reactor was started to operate under a HRT of $36 \mathrm{~h}$ and an organic loading rate of $5 \mathrm{~g}$ COD L ${ }^{-1} \mathrm{~d}^{-1}$. Results showed a COD removal percentage of $70 \%$ by the end of phase I (Fig. 1).

The combination of both HRT reduction from 36 to $24 \mathrm{~h}$ together with OLR increase from 5 to $15 \mathrm{~g}$ COD L $\mathrm{L}^{-1} \mathrm{~d}^{-1}$ led to a sharp decrease in both $\mathrm{pH}$ and removed COD (phase I, II and III, Fig. 1). Further reduction in HRT to $12 \mathrm{~h}$ (phase IV) and diminishing the OLR to $5 \mathrm{~g} \mathrm{COD} \mathrm{L}^{-1} \mathrm{~d}^{-1}$ led to a system recovery in terms of removed COD from around 23\% to $65-70 \%$ in a 2 weeks period. During this adaptation period (phase III to phase IV), the $\mathrm{pH}$ showed a faster response to the new operational parameters. Steady values were reached within 5 days (from pH 5.6 to 7.0). From phase IV to VII, HRT was kept at $12 \mathrm{~h}$ and OLR was augmented graduately from 5 to $30 \mathrm{~g} \mathrm{COD} \mathrm{L}^{-1} \mathrm{~d}^{-1}$.
During this period, both $\mathrm{pH}$ and removed COD showed a decrease from 7.0 to $6.1 \mathrm{in} \mathrm{pH}$ and from around 60 to $35 \%$ in COD removal. Due to an upset in the system, the reactor was started-up again in conditions mentioned for phase VIII (with the parameters figures of phase IV, Fig. 1). From this point, the HRT was reduced to $6 \mathrm{~h}$ and the OLR was set to $5 \mathrm{~g} \mathrm{COD} \mathrm{L} \mathrm{d}^{-1}$. The $\mathrm{pH}$ value was then between 6.8 and 6.5 and figures for COD removal stabilized around $45 \%$. During phase X, HRT was kept at $6 \mathrm{~h}$ and OLR increased to $20 \mathrm{~g} \mathrm{COD} \mathrm{L}^{-1} \mathrm{~d}^{-1}$ which led to an average $\mathrm{pH}$ of 6.6 and after a recovery of $64 \%$, COD removal showed a trend to diminish down to $35 \%$ at day 112 .

The analysis of variance (ANOVA) to study the effect of HRT and OLR on volumetric gas production rate (VGPR) showed that OLR had a significant effect $(p=0.0001)$ whereas HRT ( $p=0.1528)$ showed a weaker effect. As a consequence, and as it was expected, higher OLR resulted in higher figures of VGPR. As can be noticed in Table 1, figures above $2 \mathrm{~L}_{\text {gas }} \mathrm{L}_{\text {reactor }}^{-1} \mathrm{~d}^{-1}$ were attained only with an OLR as high as $30 \mathrm{~g} \mathrm{COD} \mathrm{L}^{-1} \mathrm{~d}^{-1}$. It is important to notice that gas identification analyses could not be performed, thus the term "gas" used here could be a mixture of $\mathrm{CH}_{4}$ and or $\mathrm{H}_{2}$.

Similar results were obtained for statistical analysis regarding $\mathrm{pH}$. For this parameter, OLR $(p=0.0001)$ exerted a stronger effect on $\mathrm{pH}$ than HRT $(p=0.0506)$. A clear trend in $\mathrm{pH}$ reduction is shown when diminishing HRT from 36 to $6 \mathrm{~h}$ (Table 1) achieving a $\mathrm{pH}=6.48$ with $\mathrm{HRT}=6 \mathrm{~h}$, although a lower figure $(\mathrm{pH}=6.29)$ was observed with OLR $=30 \mathrm{~g} \mathrm{COD} \mathrm{L}^{-1} \mathrm{~d}^{-1}$. A pH-related parameter, acidity, was also affected by $\operatorname{OLR}(p=0.0001)$ and in lesser extent by HRT ( $p=0.1696)$.

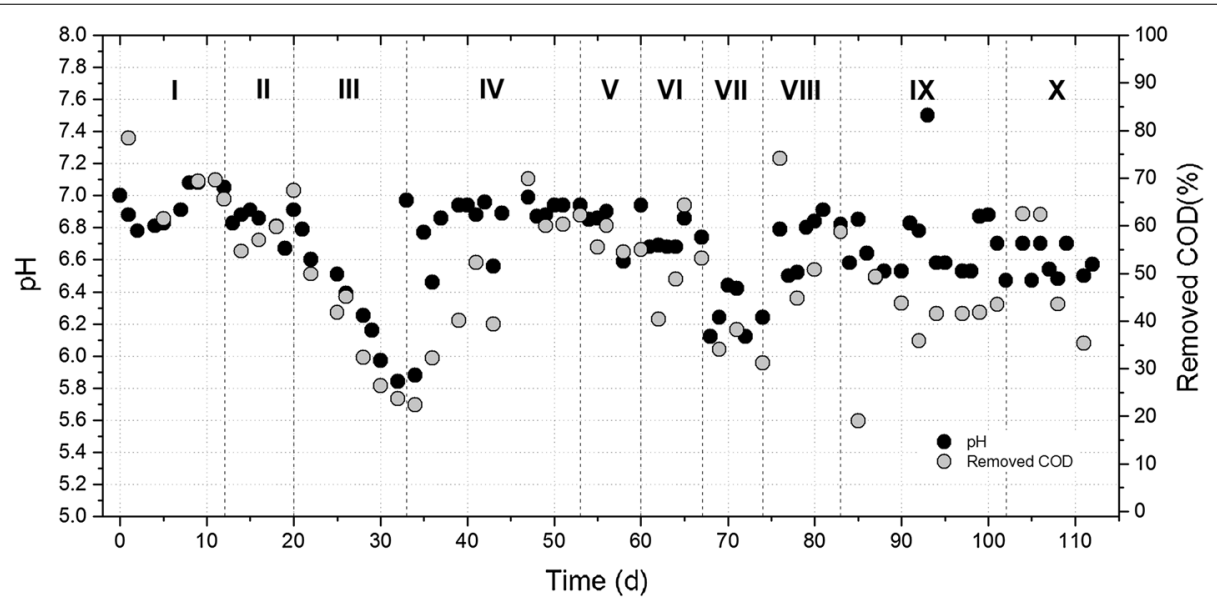

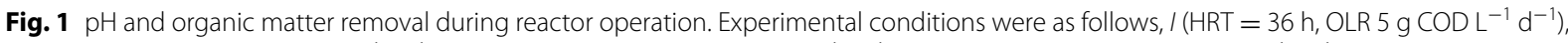

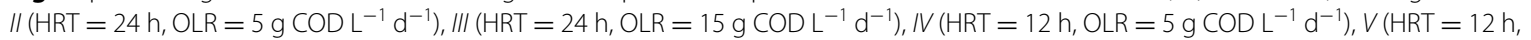
$\left.\mathrm{OLR}=10 \mathrm{~g} \mathrm{COD} \mathrm{L}^{-1} \mathrm{~d}^{-1}\right), \mathrm{VI}\left(\mathrm{HRT}=12 \mathrm{~h}, \mathrm{OLR}=20 \mathrm{~g} C O D \mathrm{~L}^{-1} \mathrm{~d}^{-1}\right), V I I\left(H R T=12 \mathrm{~h}, \mathrm{OLR}=30 \mathrm{~g} \mathrm{COD} \mathrm{L}^{-1} \mathrm{~d}^{-1}\right)$, VIII (HRT $=12 \mathrm{~h}$, $\left.\mathrm{OLR}=5 \mathrm{~g} \mathrm{COD} \mathrm{L}^{-1} \mathrm{~d}^{-1}\right), I X\left(H R T=6 \mathrm{~h}, \mathrm{OLR}=5 \mathrm{~g} \mathrm{COD} \mathrm{L}^{-1} \mathrm{~d}^{-1}\right), X\left(\mathrm{HRT}=6 \mathrm{~h}, \mathrm{OLR}=20 \mathrm{~g} \mathrm{COD} \mathrm{L}^{-1} \mathrm{~d}^{-1}\right)$. 
Table 1 Effect of operational parameters on reactor performance

\begin{tabular}{|c|c|c|c|c|c|}
\hline HRT (h) & $\operatorname{VGPR}^{a}\left(L_{\text {gas }} L_{\text {reactor }}^{-1} d^{-1}\right)$ & $\mathrm{PH}^{\mathrm{a}}$ & COD removal (\%) ${ }^{\mathrm{a}}$ & Acidity $^{\mathrm{a}}\left(\mathrm{mg} \mathrm{CaCO}_{3} \mathrm{~L}^{-1}\right)$ & Alkalinity $^{\mathrm{a}}\left(\mathrm{mg} \mathrm{CaCO}_{3} \mathrm{~L}^{-1}\right)$ \\
\hline 6 & $1.09 \pm 0.16(25)$ & $6.48 \pm 0.06(25)$ & $36.04 \pm 4.00(12)$ & $3,994.81 \pm 183.29(25)$ & $282.54 \pm 17.73(25)$ \\
\hline 12 & $1.16 \pm 0.12(40)$ & $6.57 \pm 0.04(40)$ & $44.66 \pm 2.72(24)$ & $4,120.14 \pm 133.82(40)$ & $323.58 \pm 12.94(40)$ \\
\hline 24 & $1.62 \pm 0.22(16)$ & $6.61 \pm 0.07(16)$ & $54.26 \pm 5.08(10)$ & $4,331.12 \pm 242.05(16)$ & $337.73 \pm 23.41(16)$ \\
\hline 36 & $1.49 \pm 0.23(10)$ & $6.72 \pm 0.08(9)$ & $63.47 \pm 5.64(10)$ & $3,615.65 \pm 265.74(9)$ & $351.31 \pm 25.71(9)$ \\
\hline \multicolumn{6}{|c|}{$\operatorname{OLR}\left(g \operatorname{COD} L^{-1} d^{-1}\right)$} \\
\hline 5 & $0.91 \pm 0.09(55)$ & $6.81 \pm 0.03(56)$ & $55.05 \pm 2.21(30)$ & $3,141.45 \pm 103.10(55)$ & $293.92 \pm 9.98(55)$ \\
\hline 10 & $1.02 \pm 0.28(6)$ & $6.85 \pm 0.10(5)$ & $61.15 \pm 6.19(4)$ & $3,135.29 \pm 335.92(5)$ & $312.21 \pm 32.49(5)$ \\
\hline 15 & $0.90 \pm 0.28(9)$ & $6.31 \pm 0.09(8)$ & $31.86 \pm 6.32(6)$ & $4,770.97 \pm 311.63(9)$ & $331.12 \pm 30.15(9)$ \\
\hline 20 & $1.69 \pm 0.18(15)$ & $6.71 \pm 0.06(15)$ & $60.55 \pm 4.47(8)$ & $3,592.49 \pm 207.14(15)$ & $331.50 \pm 20.04(15)$ \\
\hline 30 & $2.18 \pm 0.28(6)$ & $6.29 \pm 0.10(6)$ & $39.43 \pm 6.95(3)$ & $5,436.95 \pm 311.53(6)$ & $350.21 \pm 30.14(6)$ \\
\hline
\end{tabular}

a Mean values are reported \pm standard error, replicates for determination (n) are shown in parenthesis.

The highest COD removal rates (around 70\%) were obtained with an HRT of $36 \mathrm{~h}$ and OLR of $5 \mathrm{~g}$ COD $\mathrm{L}^{-1} \mathrm{~d}^{-1}$ (phase I) and an HRT of $12 \mathrm{~h}$ and OLR of $5 \mathrm{~g}$ COD L ${ }^{-1} \mathrm{~d}^{-1}$ (phase IV). The lowest COD removal rates (around 36\%) were obtained with a HRT of 6 h (Table 1). This HRT promoted the production and accumulation of VFA in the system (4116.12 $\mathrm{mg}$ total VFA $\mathrm{L}^{-1}$; Table 2), reaching the highest VFA concentration in this experiment. The volumetric gas production obtained with a HRT of $6 \mathrm{~h}$ was $1.09 \mathrm{~L}_{\text {gas }} \mathrm{L}_{\text {reactor }}^{-1} \mathrm{~d}^{-1}$ (Table 1 ).

\section{Microbial analysis}

Results from bacterial analysis by PCR-DGGE of partial 16S rRNA genes are shown in Fig. 2. Six bands were successfully excised and DNA sequenced for identification of bacteria that adapted to process conditions and were present in the reactor at the end of the experiment. Bands numbered 1, 2, 3 and 5, resulted with the highest intensity in the DGGE gel (Fig. 2a), which is indicative of its relative abundance in this semi-quantitative analysis. Sequencing of the DNA retrieved from most intense bands resulted in the identification of Clostridium sp.
MB9-7, Clostridium pasteurianum DSM 525, Clostridium tyrobutyricum ATCC 25755 and Clostridium pasteurianum BC1. Moreover, Clostridium acidisoli CK74 (Band 4) and Clostridium thermopalmarium NMY5 (Band 6), were also identified in the reactor biomass (Fig. 2).

\section{Discussion}

As can be noticed from Fig. 1, there is a strong correlation in similar responses for $\mathrm{pH}$ and COD removal parameters during reactor operation (Fig. 1). This makes the $\mathrm{pH}$ an interesting parameter to predict the expected COD removal in future studies.

Regarding the operation parameters (HRT and OLR) in the reactor start-up, they are in accordance with the startup values presented by Jauregui-Jauregui et al. (2014) for an anaerobic reactor fed with Tequila vinasses intended for methane production. Jauregui-Jauregui et al. (2014) obtained similar removal rates during the start-up of their reactor, with methane contents around 60-70\% $(\mathrm{v} / \mathrm{v})$ under these conditions. When they reached an OLR of $5 \mathrm{~g} \mathrm{COD} \mathrm{L}^{-1} \mathrm{~d}^{-1}$, their HRT and COD removal were

Table 2 Effect of operational parameters on volatile fatty acids production

\begin{tabular}{|c|c|c|c|c|c|}
\hline HRT (h) & Acetic $^{a}\left(\mathrm{mg} \mathrm{L}^{-1}\right)$ & Propionic $^{\mathrm{a}}\left(\mathrm{mg} \mathrm{L}^{-1}\right)$ & Butyric $^{\mathrm{a}}\left(\mathrm{mg} \mathrm{L}^{-1}\right)$ & Valeric $^{\mathrm{a}}\left(\mathrm{mg} \mathrm{L}^{-1}\right)$ & Isovaleric $^{\mathrm{a}}\left(\mathrm{mg} \mathrm{L}^{-1}\right)$ \\
\hline 6 & $921.37 \pm 18.62(12)$ & $783.03 \pm 18.92(12)$ & $1,460.81 \pm 19.09(12)$ & $375.78 \pm 12.32(12)$ & $575.13 \pm 21.46(12)$ \\
\hline 12 & $866.94 \pm 12.00(29)$ & $702.55 \pm 12.19(29)$ & $1,131.95 \pm 12.31(29)$ & $367.74 \pm 7.94(29)$ & $536.30 \pm 13.83(29)$ \\
\hline 24 & $629.38 \pm 23.95(11)$ & $453.61 \pm 24.32(11)$ & $898.34 \pm 24.56(24)$ & $265.73 \pm 15.85(11)$ & $318.63 \pm 27.60(11)$ \\
\hline 36 & $593.57 \pm 26.70(5)$ & $434.07 \pm 27.12(5)$ & $722.87 \pm 27.38(5)$ & $222.63 \pm 17.67(5)$ & $211.95 \pm 30.77(5)$ \\
\hline \multicolumn{6}{|c|}{$\operatorname{OLR}\left(g \operatorname{COD} \mathrm{L}^{-1} \mathrm{~d}^{-1}\right)$} \\
\hline 5 & $700.11 \pm 10.58(31)$ & $515.23 \pm 10.75(31)$ & $970.73 \pm 10.85(31)$ & $319.32 \pm 7.00(31)$ & $421.89 \pm 12.20(31)$ \\
\hline 10 & $716.13 \pm 29.65(4)$ & $560.87 \pm 30.12(4)$ & $1,038.39 \pm 30.40(4)$ & $313.63 \pm 19.62(4)$ & $393.10 \pm 34.17(4)$ \\
\hline 15 & $873.36 \pm 29.32(7)$ & $752.59 \pm 29.78(7)$ & $1,123.09 \pm 30.06(7)$ & $342.90 \pm 19.40(7)$ & $588.47 \pm 33.79(7)$ \\
\hline 20 & $725.39 \pm 20.51(9)$ & $587.44 \pm 20.82(9)$ & $1,004.84 \pm 21.02(9)$ & $276.83 \pm 13.57(9)$ & $361.65 \pm 23.63(9)$ \\
\hline 30 & $749.08 \pm 25.43(6)$ & $550.45 \pm 25.83(6)$ & $1,130.41 \pm 26.07(6)$ & $287.18 \pm 16.83(6)$ & $287.40 \pm 29.30(6)$ \\
\hline
\end{tabular}

a Mean values are reported \pm standard error, replicates for determination ( $n$ ) are shown in parenthesis. 


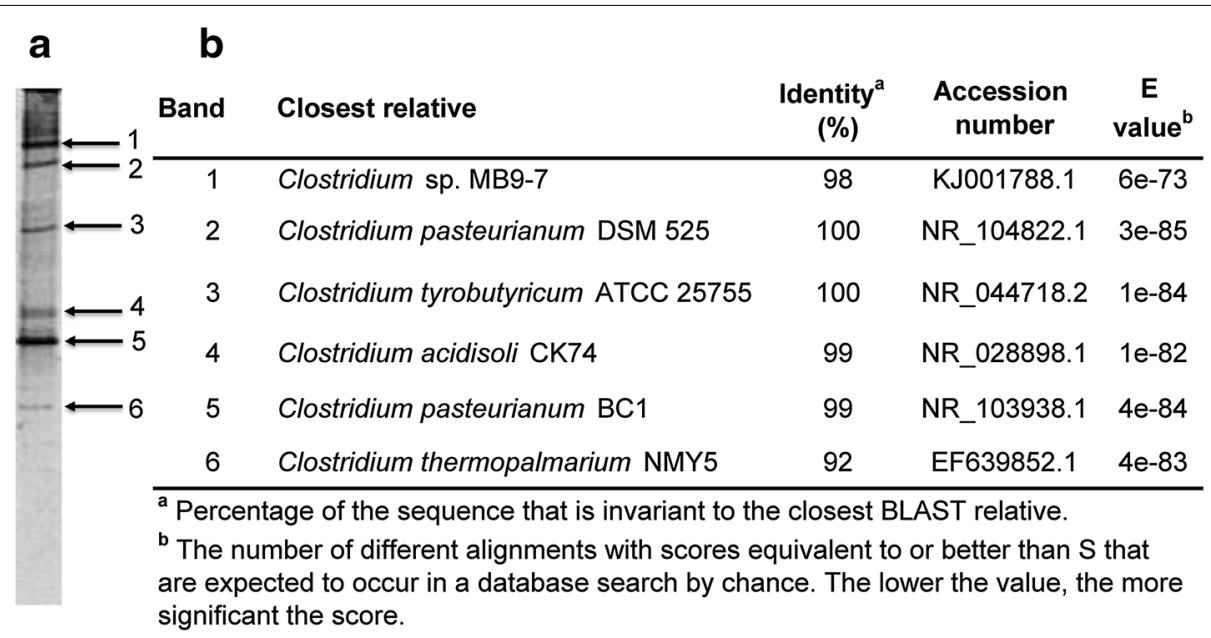

Fig. 2 Bacterial identification of adapted microorganisms: a DGGE gel. b Identity of microorganisms present at the end of the experiment.

around $48 \mathrm{~h}$ and $70 \%$ respectively. In the present study, it was shown that this COD removal could be maintained at lower HRT values ( $12 \mathrm{~h}$ in phase IV).

In a recent study by Buitrón et al. (2014a), the authors assessed the hydrogen production performance in a SBR (sequencing batch reactor) using Tequila vinasses as substrate, with a HRT of $6 \mathrm{~h}$. Under this condition they reached a peak hydrogen production of $57.4 \mathrm{~mL}_{\mathrm{H} 2}$ $\mathrm{L}_{\text {reactor }}^{-1} \mathrm{~h}^{-1}\left(1.37 \mathrm{~L}_{\mathrm{H} 2} \mathrm{~L}_{\text {reactor }}^{-1} \mathrm{~d}^{-1}\right)$ with a COD removal of $18 \%$. Further research by the same group (Buitrón et al. 2014b) improved their results using a fixed bed reactor under continuous regime obtaining $72 \mathrm{~mL}_{\mathrm{H} 2} \mathrm{~L}_{\text {reactor }}^{-1} \mathrm{~h}^{-1}$ $\left(1.72 \mathrm{~L}_{\mathrm{H} 2} \mathrm{~L}_{\text {reactor }}^{-1} \mathrm{~d}^{-1}\right)$ with a HRT of $4 \mathrm{~h}$ and a OLR of 51 gCOD L $\mathrm{L}^{-1} \mathrm{~d}^{-1}$ achieving a carbon removal of $20 \%$. As discussed by some authors, a short HRT is a selective pressure towards hydrogen-producing microorganisms selection, therefore it is suggested that volumetric hydrogen production rate obtained recently by other authors (Buitrón et al. 2014a, b) are comparable to our results under the HRT of $6 \mathrm{~h}$. Despite the fact that gas identification could not be performed for our study, VFA levels, $\mathrm{pH}$ conditions achieved during bioreactor operation and the prevalence of Clostridia suggest that the main gas produced should be $\mathrm{H}_{2}$.

In a recent study (Wu et al. 2014), Clostridium sp. MB9-7 was genetically characterized and closely related to C. tyrobutiricum. Biochemical tests showed that this strain fermented glucose, xylose and mannose with butyrate, acetate, carbon dioxide and hydrogen as main products. On the other hand, C. pasteurianum $\mathrm{BC} 1$ was reported by Yarlagadda et al. (2012) as a fermentative organism which performed hydrogen, acetic and butyric acid production (acidogenesis) from glucose and could be directed to solventogenesis (ethanol and butanol production) with the aid of exogenous electron shuttles. Besides, it is noteworthy to mention that C. pasteurianum $\mathrm{BC} 1$ (ATCC 53464) was isolated from an acidic metal contaminated site, and has demonstrated efficient reduction of several redox-active metals in mineral salts medium. This strain was also found to be a rapid and efficient glucose fermenter compared to other clostridia strains, such as Clostridium acetobutylicum (ATCC 19403), Clostridium sphenoides (ATCC 19403), and C. pasteurianum (ATCC 7040) (Francis et al. 2008; Gao and Francis 2008). Moreover, C. pasteurianum DSM 525 which also was present in the system (Fig. 2) has been reported as an efficient butanol producer from thin stillage (Ahn et al. 2011). These authors demonstrated the feasibility of cost-effective butanol production by C. pasteurianum DSM 525 using thin stillage as a nutrient-containing medium.

On the other hand, Clostridium acidisoli CK74 was also identified in the reactor biomass (Fig. 2). This strain was studied by Kuhner et al. (2000) and characterized as nonacetogenic, $\mathrm{N}_{2}$-fixing, fermentative chemo-organotroph. The authors reported that this strain was isolated from acidic peat-bog soil, and had the ability to grow on substrates such as glucose, cellobiose, xylose, arabinose, maltose, mannose, salicin, mannitol, lactose, sucrose, glycerol, melezitose, raffinose and rhamnose. Growth of the strain on glucose yielded butyrate, lactate, acetate, formate, $\mathrm{H}_{2}$ and $\mathrm{CO}_{2}$ as end products. Showed growth at $5-37^{\circ} \mathrm{C}$ with an optimum between 25 and $30^{\circ} \mathrm{C}$. Moreover, the doubling time on glucose was near $3.5 \mathrm{~h}$ (at $\mathrm{pH}=4$ and $30^{\circ} \mathrm{C}$ ) (Kuhner et al. 2000).

Immobilized C. tyrobutyricum ATCC 25755 strain grown under continuous culture was studied by Mitchell et al. (2009). The effects of the hydraulic retention time 
$(\mathrm{HRT}=8,10,12$ or $16.7 \mathrm{~h})$ and glucose concentration (30, 40 or $50 \mathrm{~g} \mathrm{~L}^{-1}$ ) on the production of hydrogen and butyrate were evaluated. Higher biogas and hydrogen production rates were generally seen when the HRT was lower. That study found the best conditions for the continuous production of hydrogen and butyric acid by C. tyrobutyricum to be with an HRT of $12 \mathrm{~h}$ and a glucose concentration of $50 \mathrm{~g} \mathrm{~L}^{-1}$, respectively. The previous reports for the Clostridium strains that were found in the reactor are important to consider new operation conditions for optimization in hydrogen production from Tequila vinasses. Our findings are relevant since acidogenesis of Tequila vinasses using identified and studied microorganism abilities (i.e. Clostridium strains) presents the opportunity of considering the process different than a "black box" concept and to optimize it depending on the microorganism and process conditions for different metabolites production (butanol, VFA, hydrogen, solvents).

The identification of Clostridium species only suggests that gas volumes reported here could be hydrogenenriched streams which remains to be verified in future studies. It is noteworthy to mention that both inoculum selection and probably acidogenic conditions in the UASB reactor selected microorganisms that are capable to grow on acidic conditions (C. pasteurianum $\mathrm{BC}$, C. acidisoli CK74) and also with the ability to utilize a wide variety of substrates; both abilities crucial for being able to metabolise Tequila vinasses, a complex acidic wastewater.

\section{Conclusions}

Volatile fatty acids (VFA) were produced from Tequila vinasses in a continuous regime with results similar to other reports using semi-continuous and continuous processes with the same class of substrate but different reactor configuration.

The most relevant from our report is that bacterial identification of the sludge sample at the end of the experiment revealed that acid-tolerant microorganisms that remained in the reactor were exclusively affiliated to the Clostridium genera, being this the first report of organisms identification responsible for Tequila vinasses acidogenesis. These findings are relevant to the field of biotechnology since acidogenesis of Tequila vinasses using identified and studied microorganism abilities (i.e. Clostridium strains) presents the opportunity of optimizing different processes intended for different metabolites production (butanol, VFA, hydrogen, solvents).

\section{Author's contributions}

LCR and RCCA performed the experiments. ENMM and REBR carried out the molecular studies. GDV, ENMM and SMCR participated in the design of the study and performed the statistical analysis. GDV and ENMM conceived of the study, and participated in its design and coordination and helped to draft the manuscript. All authors read and approved the final manuscript.

\section{Author details}

${ }^{1}$ Biotecnología Médica y Farmacéutica, Centro de Investigación y Asistencia en Tecnología y Diseño del Estado de Jalisco, Av. Normalistas 800, Col. Colinas de la Normal, C.P. 44270 Guadalajara, Jalisco, Mexico. ${ }^{2}$ Tecnología Ambiental, Centro de Investigación y Asistencia en Tecnología y Diseño del Estado de Jalisco, Av. Normalistas 800, Col. Colinas de la Normal, C.P. 44270 Guadalajara, Jalisco, Mexico.

\section{Acknowledgements}

The authors are indebted to Julissa E. López-Ramírez for the technical assistance with the GC analyses.

\section{Compliance with ethical standards}

\section{Competing interest}

The authors declare that they have no competing interests.

\section{Informed consent}

Besides, this article does not contain any studies with human participants or animals performed by any of the authors. Informed consent was obtained from all individual participants included in the study.

Received: 7 May 2015 Accepted: 29 July 2015

Published online: 14 August 2015

\section{References}

Ahn JH, Sang BI, Um Y (2011) Butanol production from thin stillage using Clostridium pasteurianum. Bioresour Technol 102(7):4934-4937. doi:10.1016/j.biortech.2011.01.046

APHA, AWWA, WEF (1998) Standard methods for the examination of water and wastewater. 20th edn. American Public Health Association (APHA), American Water Works Association (AWWA), Water Environment Federation (WEF), Washington DC

Bengtsson S, Hallquist J, Werker A, Welander T (2008) Acidogenic fermentation of industrial wastewaters: effects of chemostat retention time and $\mathrm{pH}$ on volatile fatty acids production. Biochem Eng J 40(3):492-499. doi:10.1016/j.bej.2008.02.004

Buitrón G, Carvajal C (2010) Biohydrogen production from Tequila vinasses in an anaerobic sequencing batch reactor: effect of initial substrate concentration, temperature and hydraulic retention time. Bioresour Technol 101(23):9071-9077. doi:10.1016/j.biortech.2010.06.127

Buitrón G, Kumar G, Martinez-Arce A, Moreno G (2014a) Hydrogen and methane production via a two-stage processes $\left(\mathrm{H}_{2}-\mathrm{SBR}+\mathrm{CH}_{4}-\mathrm{UASB}\right)$ using tequila vinasses. Int J Hydrogen Energ 39(33):19249-19255. doi:10.1016/j. ijhydene.2014.04.139

Buitrón G, Prato-Garcia D, Zhang A (2014b) Biohydrogen production from tequila vinasses using a fixed bed reactor. Water Sci Technol 70(12):19191925. doi:10.2166/wst.2014.433

Chen Y, Cheng JJ, Creamer KS (2008) Inhibition of anaerobic digestion process: a review. Bioresour Technol 99(10):4044-4064. doi:10.1016/j. biortech.2007.01.057

CNIT (2015) Información básica de la industria tequilera. Cámara Nacional de la Industria Tequilera (CNIT). http://www.tequileros.org/stuff/file_estadistica/1405441294.pdf. Accessed 20 Feb 2015

CRT (2015a) Geography: the territory of the appellation of origin, or TDO. Consejo Regulador del Tequila (CRT). http://www.crt.org.mx/index. php?option=com_content\&view=article\&id=175\&ltemid=185\&lang $=$ en. Accessed 20 Feb 2015

CRT (2015b) Información Estadística. Consejo Regulador del Tequila (CRT). http://www.crt.org.mx/EstadisticasCRTweb/. Accessed 20 Feb 2015

Davila-Vazquez G, Arriaga S, Alatriste-Mondragón F, de León-Rodríguez A, Rosales-Colunga LM, Razo-Flores E (2008) Fermentative biohydrogen production: trends and perspectives. Rev Environ Sci Biotechnol 7(1):27-45. doi:10.1007/s11157-007-9122-7

Davila-Vazquez G, de León-Rodríguez A, Alatriste-Mondragón F, Razo-Flores E (2011) The buffer composition impacts the hydrogen production and the microbial community composition in non-axenic cultures. Biomass Bioenerg 35(7):3174-3181. doi:10.1016/j.biombioe.2011.04.046 
Espinoza-Escalante F, Pelayo-Ortiz C, Gutiérrez-Pulido H, González-Álvarez V, Alcaraz-González V, Bories A (2008) Multiple response optimization analysis for pretreatments of Tequila's stillages for VFAs and hydrogen production. Bioresour Technol 99(13):5822-5829. doi:10.1016/j. biortech.2007.10.008

Espinoza-Escalante F, Pelayo-Ortíz C, Navarro-Corona J, González-García Y Bories A, Gutiérrez-Pulido H (2009) Anaerobic digestion of the vinasses from the fermentation of Agave tequilana Weber to tequila: the effect of $\mathrm{pH}$, temperature and hydraulic retention time on the production of hydrogen and methane. Biomass Bioenerg 33(1):14-20. doi:10.1016/j. biombioe.2008.04.006

Francis AJ, Dodge CJ, Gillow JB (2008) Reductive dissolution of Pu(IV) by Clostridium sp. under anaerobic conditions. Environ Sci Techno 42(7):2355-2360. doi:10.1021/es072016w

Gao W, Francis AJ (2008) Reduction of uranium(VI) to uranium(IV) by clostridia. Appl Environ Microbiol 74(14):4580-4584. doi:10.1128/AEM.00239-08

Hernández-Mendoza CE, Moreno-Andrade I, Buitrón G (2014) Comparison of hydrogen-producing bacterial communities adapted in continuous and discontinuous reactors. Int J Hydrogen Energ 39(26):14234-14239. doi:10.1016/j.jijhydene.2014.01.014

Ilangovan K, Linerio J, Briones R, Noyola A (2000) Anaerobic treatment of tequila vinasse. In: Olguin EJ, Sanchez G, Hernandez E (eds) Environmental biotechnology and cleaner bioprocesses, 1st edn. Taylor \& Francis, London, pp 101-106

Jauregui-Jauregui JA, Mendez-Acosta HO, Gonzalez-Alvarez V, Snell-Castro R, Alcaraz-Gonzalez V, Godon JJ (2014) Anaerobic treatment of tequila vinasses under seasonal operating conditions: start-up, normal operation and restart-up after a long stop and starvation period. Bioresour Technol 168:33-40. doi:10.1016/j.biortech.2014.04.006

Kuhner CH, Matthies C, Acker G, Schmittroth M, Gossner AS, Drake HL (2000) Clostridium akagii sp nov and Clostridium acidisoli sp nov.: acid-tolerant, $\mathrm{N}_{2}$-fixing clostridia isolated from acidic forest soil and litter. Int J Syst Evol Micr 50:873-881. doi:10.1099/00207713-50-2-873

López-López A, Davila-Vazquez G, León-Becerril E, Villegas-García E, GallardoValdez J (2010) Tequila vinasses: generation and full scale treatment processes. Rev Environ Sci Biotechnol 9(2):109-116. doi:10.1007/ s11157-010-9204-9

Mendez-Acosta HO, Garcia-Sandoval JP, Gonzalez-Alvarez V, Alcaraz-Gonzalez

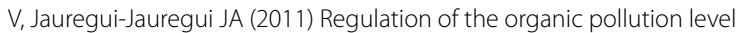
in anaerobic digesters by using off-line COD measurements. Bioresour Technol 102(17):7666-7672. doi:10.1016/j.biortech.2011.05.053

Méndez-Acosta HG, Snell-Castro R, Alcaraz-González V, González-Álvarez $\checkmark$, Pelayo-Ortiz C (2010) Anaerobic treatment of Tequila vinasses in a CSTR-type digester. Biodegradation 21(3):357-363. doi:10.1007/ s10532-009-9306-7

Mitchell RJ, Kim JS, Jeon BS, Sang BI (2009) Continuous hydrogen and butyric acid fermentation by immobilized Clostridium tyrobutyricum ATCC 25755: effects of the glucose concentration and hydraulic retention time. Bioresour Technol 100(21):5352-5355. doi:10.1016/J.Biortech.05.046

Pant D, Adholeya A (2007) Biological approaches for treatment of distillery wastewater: a review. Bioresour Technol 98(12):2321-2334. doi:10.1016/j. biortech.2006.09.027

Park W, Hyun SH, Oh SE, Logan BE, Kim IS (2005) Removal of headspace $\mathrm{CO}_{2}$ increases biological hydrogen production. Environ Sci Technol 39(12):4416-4420. doi:10.1021/es048569d

Retes-Pruneda JL, Davila-Vazquez G, Medina-Ramírez I, Chavez-Vela NA, Lozano-Alvarez JA, Alatriste-Mondragon F et al (2014) High removal of chemical and biochemical oxygen demand from tequila vinasses by using physicochemical and biological methods. Environ Technol 35(14):1773-1784. doi:10.1080/09593330.2014.882960

Silva FC, Serafim LS, Nadais H, Arroja L, Capela I (2013) Acidogenic fermentation towards valorisation of organic waste streams into volatile fatty acids. Chem Biochem Eng Q 27(4):467-476

Wu YF, Zheng H, Wu QL, Yang H, Liu SJ (2014) Clostridium algifaecis sp. nov, a novel anaerobic bacterial species from decomposing algal scum. Int J Syst Evol Microbiol. doi:10.1099/ijs.0.064345-0

Yarlagadda VN, Gupta A, Dodge CJ, Francis AJ (2012) Effect of exogenous electron shuttles on growth and fermentative metabolism in Clostridium sp. BC1. Bioresour Technol 108:295-299. doi:10.1016/j.biortech.2011.12.040

\section{Submit your manuscript to a SpringerOpen ${ }^{\odot}$ journal and benefit from:}

- Convenient online submission

- Rigorous peer review

- Immediate publication on acceptance

- Open access: articles freely available online

- High visibility within the field

- Retaining the copyright to your article

Submit your next manuscript at springeropen.com 